\title{
THE REGIONAL COOPERATION IN EUROPE. FROM THE MADRID CONVENTION TO THE MACRO-REGIONAL APPROACH
}

The cooperation of regional authorities in Europe is made possible owing to the existence of international conventions and internal documents of the European Union. The international instruments governing the interregional relations European regions consist of the European Framework Convention on the Transfrontier Cooperation between the Territorial Communities or Authorities (the Madrid Convention); ${ }^{1}$ the European Charter of the local government (local) of October $15^{\text {th }}, 1985$; the European Charter of Border Regions and the Cross-Border dated for 1995; the European Charter of the Regional Self-Government; ${ }^{2}$ and the Additional Protocol to the European Framework Convention on the Cross-Border Cooperation between Territorial Authorities and Communities of 1998. The internal acts include the Annexed Community Charter for Regionalization, and the macro-regional strategies.

The Madrid Convention is a document of the Council of Europe ${ }^{3}$ dated for May $21^{\text {st }}$, 1980. Poland ratified this document on March $10^{\text {th }}, 1993$, with effect

\footnotetext{
mgr Marta Szulc, doktorantka w Instytucie Politologii i Europeistyki Uniwersytetu Szczecińskiego, e-mail: szulcmv@gmail.com.

$1 \quad$ K. Kokocińska, Polityka regionalna w Polsce i w Unii Europejskiej. Poznań: Wydawnictwo Naukowe Uniwersytetu im. Adama Mickiewicza 2009: 57. 1997.

2 The draft European Charter of the regional self-government was adopted on June 5th,

3 The Council of Europe is an international organization set up on May 5th, 1949 by ten European countries. It currently brings together 41 countries. The seat of the Council of Europe is the Palace of Europe in Strasbourg, France. The aim of the Council of Europe according to the Statute is "to achieve the connection between its members for the protection and promotion of the ideals and principles which are their common heritage and to contribute to their economic and social progress." For details see e.g. E. Latoszek, M. Proczak. International Organizations in Today's World. Warsaw: Wydawnictwo Naukowe Wydziału Zarządzania Uniwersytetu Warszawskiego 2006: 349-396.
} 
of June $19^{\text {th }}$, 1993. The Convention has been divided into two parts. Its first part comprises the preamble and 12 articles depicting the international law standards and obligations binding for the States - parties to the Convention. The second part contains model contracts, agreements and statutes concerning the cross-border cooperation. These documents are only suggestions as regards the institutionalization and formalization of the cross-border cooperation and, therefore, shall have no binding force. ${ }^{4}$

The main objective of the Convention is promoting cooperation and verifying cross-border relations. The rules highlight both the responsibilities of the Member States in relation to one another and the rules affecting the freedom of territorial units during the cooperation. The Convention only presupposes that the States - parties mutually undertake to promote and facilitate cross-border cooperation between own territorial units, and are ready to conclude, for this purpose, bilateral agreements at the intergovernmental and inter-State level. The signatory States of the Convention have an obligation to remove problems and legal, administrative and technical difficulties that may interfere with the development of cross-border relations both at the regional and local levels. ${ }^{5}$

The Madrid Convention contains two basic principles of the cross-border cooperation. They are:

- national law priority principle as it relates to local and regional agreements concluded between the cooperation partners,

- territorial units' competence integrity principle as designated in the native law. ${ }^{6}$

According to the provisions of the Convention, the cooperation between territorial units should include:

- local and regional development,

- protection of the environment,

- improving infrastructure and raising the level and quality of services to the public,

- mutual assistance in the event of misfortunes and disasters. ${ }^{7}$

The European Charter of the Local Government (local) of 15 October 1985 is an act of international law in the sense that its signatories have ratified it. The

\footnotetext{
Z. Brodecki (ed.). Regiony. Warszawa: Wydawnictwo Naukowe PWN 2005: 226.

Ibidem: 227

Ibidem.

K. Tomaszewski, Regiony w procesie integracji europejskiej. Kraków: Wolters Kluwer
}

2007: 107. 
card standardizes the legal basis both of the local government's organization and operation and of its ensuring "local democracy" for the Member States within the Council of Europe, while respecting the systemic solutions and historical heritage of each of them. ${ }^{8}$

Art. 10 of the Card ("the right of local communities to get united") has been devoted to interregional cooperation:

1. "Executing their powers, local communities have the right to cooperate with other local communities and bring together with them - within the limits laid down by law-in order to carry out tasks that are a matter of common interest.

2. The right of local communities to join the Association in order to protect and develop common interests and the right to join the International Association of local communities will be recognized in each State.

3. Local communities can collaborate with communities of other Member States under the conditions provided for by law."

Article 10 specifies the European standard for interregional cooperation. It states that regions have the right to cooperate so as to implement the action of interest to the cooperating parties. Also, the article obliges the Member States to recognize the right to form associations of local communities within the framework of the international associations of these communities.

The European Charter of the Regional Self-Government of June 5, 1997 is a document that describes in more detail the role and potential of the region in its relations with other regions. First of all, the Card that designates the region demarcates it as the "public administration level existing between the Government and the local government with: the separate from the State and local units, legal personality, the elected regulatory authority, its own enforcement and administrative bodies, the budget plus own income sources, and the ranging tasks and competences." 9 The interregional cooperation issues are the subject of two articles: Art. 10 on the "participation in European and international affairs," and Art. 8 on the interregional and cross-border relations."

Article 10 (1) provides that: "the regions should have the right to participate or to be represented by a body specially designed for this purpose-in the activities of the European institutions." This regulation should be interpreted as a directive

Z. Brodecki, op.cit., p. 223.

9 Ibidem. 
requiring State authorities to refrain from action that could hinder or prevent the participation of the regions from the work of the European institutions. ${ }^{10}$

Article 10 Paragraph 1.2 regulates the participation of the regions in the state adoption of international obligations as regards the State itself. It reads as follows: "the regions should have at least ensured right of giving professional advice by Governments, when the State negotiates the final shape the international treaty or adopts other legal acts in the framework of the European organisations that may directly affect their competencies or essential interests. The same should apply to the implementation of the adopted provisions at European level, which may be the responsibility of the regions."

Article 10 Paragraph 3 gives an example of how to participate in international decision-making affecting the interests of the region. It reads: "Governments may include regions in the negotiation process, in particular through the inclusion of representatives of the State delegation."

Article 10 Paragraph 4 concerns the possibility of establishing liaison offices to promote and defend the regions' interests. "To promote and defend their interests, the regions should have the right to establish-or jointly with other regions or local authorities, or individually-liaison with other regions or local authorities, or with international organisations, particularly the European organisations, active in their areas of authority."

The essence of regional cooperation can also be demonstrated via Article 8 Paragraph 1.1: "in the fields within their competence the regions should be allowed to engage in cross-border and interregional cooperation in accordance with the procedures laid down by national law. This cooperation should be carried out in accordance with national law and international obligations of the State." This article sets the international policy rules for the European regions.

The European Border Regions and Cross-Border is a document created in 1981 within the framework of the deliberations of the forum of the Association of European Border Regions. The document's necessary updates were made in 1995. The European Border Regions and Cross-Border Cooperation is a statement, hence an international legal act. It is an example of the so-called soft international law. ${ }^{11}$

The Card is recognised for the intentions and purposes which should be taken into account when the development of border regions and cross-border is at stake. Within the Card, special space has been devoted to the problems of regional

10 Ibidem: 232.

11 K. Tomaszewski, op.cit., pp. 107-108. 
policy, economic development, cultural cooperation, protection of the environment, spatial planning and border passenger traffic. The Card postulates creating a basis for the mutual trust and cooperation between neighbours. ${ }^{12}$

The first considerations over the regionalism and regions' cooperation within the European communities appeared in the Treaty of Rome. The document concerns reducing differences between regions rather than deals with the region as a separate entity. Therefore, as regards this particular document, of interest to us can only be the economic issues which relate to developmental differences. ${ }^{13}$

The first region-related instrument was the European Regional Development Fund. Formed in 1975, the Fund had a chance of becoming the commencement of the "coherence policy." 14

The Card is the European Parliament Resolution on Regionalisation, and, more specifically, an appendix to the Resolution of the Community Regional Policy and the Role of the Regions. The resolution was supposed to bring the attention of the Governments of the Member States to the issue of regionalisation of structures as well as inspire new legal arrangements on the national level. The European Parliament has been keen on the unification or standardization of local government structures.

Article 23 Paragraph 3 states that the Member States enable and support cross-border cooperation between territorial units within various Member States. This article determines the favourable treatment of such relations to be of internal nature. $^{15}$

In response to the changes that took place in the Baltic Sea Region (RMB), the European Parliament, in its report dated for the end of 2006 called for the development of the Baltic Sea Region strategy (SUE RMB), the document and concept being drawn up in favour of the regional cohesion development. The next stage was to turn, in the final remarks of the Presidency of 14 December 2007, to the European Commission to present the SUE RMB document by the end of June 2009. ${ }^{16}$

12 Ibidem.

13 J. Jaskiernia, „Regionalizm jako wartość w systemach aksjologicznych Rady Europy i Unii Europejskiej.” Regiony Europy. Ed. A. Stępień-Kuczyńska, K. Dośpiał-Borysiak, R. Łoś. Toruń: Wydawnictwo Adam Marszałek 2009: 74-77.

14 Ibidem.

15 Brodecki, op.cit., p. 252.

16 Cf. "Communication from the Commission to the European Parliament, the Council, the European Economic and Social Committee and the Committee of the Regions Concerning the European Union strategy for the Baltic Sea Region,” http://ec.europa.eu/regional_policy/sources/ docoffic/official/communic/baltic/com_baltic_pl.pdf. Accessed: 15.03.2014. 
Many organizations took part in strategizing the region. From the perspective of the cooperation as it has been carried out by the West Pomeranian Province it is worth to mention both the southern Baltic Sea Parliamentary Forum working groups $^{17}$ and the BSSSC.

During the VII Forum held in July 2009, the possibility of the strategy implementation was discussed. The proposals appearing in the Forum beforehand were also mentioned. The proposals included the implementation of the HELCOM action plan, energy policy and climate change, the Clean Baltic Shipping; and the implementation of the European internal market, fisheries, tourism and cultural heritage-historical, transport policy and maritime policy. The Forum gladly accepted that so many of these proposals in/directly became part of in the strategy. The Forum turned to the European Parliament and the Council of the European Union for equalizing the development opportunities for all the regions in the course of a legislative process. Consequently, the necessity of the constant strategy development and improvement that ensures the participation of all regions became the Forum's binding theme.

BSSSC paid attention to SUE RMB in 2008. In the course of The 16th Ordinary Conference BSSSC gladly accepted the proposal of The Baltic Sea Strategy presenting BSR as a secure region carrying out the balanced policy of environmental protection, and of the economic and social prosperity. With regard to details, the European Commission was called to present the Plan for implementing the actions and projects and establishing the responsible authorities and institutions and financial instruments. In addition, the Commission presented its high opinion of the close relationship existing between the SUE RMB and the European Maritime Strategy. BSR was also assessed as a sea region where the best European practices could be realized. Maintaining the close relationship between the Adaptation to Climate Change in Europe, and the EU Baltic Sea Strategy was emphasized, too, as well as the fact that the BSR potential could flourish only in the situation of the interregional and cross-border cooperation between neighbours. The Strategy was conceived of as referring to the cooperation with other EU sea regions. BSSSC undertook the coordination of the joint (i.e. together with

17 The Southern Baltic Sea Parliamentary Forum is an organization for interregional cooperation, focusing on the regional parliaments of the Baltic Sea States. The Forum took place on April 25-7, 2004 in Gdańsk as a follow up of the cooperation Westpomerania Region - Meklemburg which began in 2001. The Westpomerania region is represented by the Westpomeranian Regional Assembly. Cross-border Cooperation. Vol. VI: "Perspective of Cross-Border Cooperation in the Baltic Sea after the Enlargement of the European Union to the East." Schwerin, The Archives of the Department of International Cooperation of the West Pomeranian Region 2004: $5-46$. 
other organisations) contribution of the work related to the shape of The Baltic Sea Strategy as well. It was emphasized that the resulting document should support organizations and cooperation groups operating in BSR so as to avoid work doubling. ${ }^{18}$

The Commission, after the execution of social consultations carried out in 2008-2009, has published a communication on SUE RMB. The press release concentrated on a number of challenges and opportunities for the region enabling the elimination of the differences between the Baltic countries and regions. At the same time the Commission remarked that the region had the potential to become a model region for the cooperation in the European Union. ${ }^{19}$

The publication of the communication by the Commission in June 2009 was not tantamount to its implementation. The Strategy's implementation as an EU document became possible on September 26, 2009, when its conclusions were adopted. In its final wording, the Strategy's main areas comprised: ${ }^{20}$

- creating the conditions for a sustainable environment,

- the development of prosperity in the region,

- increasing the availability and attractiveness of the region,

- ensuring safety and security in the region.

In the Action Plan - one of the three documents describing the strategy - there are 15 priorities - extensions of the main areas of the strategy. As part of the conversion of RMB in the area of the sustainable environmentally, there stand out the following:

1. "reducing the amount of nutrients in the sea to acceptable levels,

2. preservation of natural zones and biodiversity, including fisheries,

3. restriction of the use and impact of hazardous substances,

4. the creation of ecological conditions in the region, standard shipping,

5. mitigate the effects of climate change and adaptation to it. ${ }^{21}$ "

In the RMB conversion area as regards welfare we read:

1. "The removal of obstacles to the internal market in the Baltic Sea Region, including improving cooperation in the field of customs and taxation,

18 "The BSSSC Resolution at the 16th Annual Conference of the Baltic Sea States' SubRegional Co-Operation (BSSSC) in Kaunas, Lithuania in September 15-17, 2008." The Archives of the Department of International Cooperation of the West Pomeranian Region.

19 Ibidem.

20 Ibidem.

${ }_{21} \quad$ “The Action Plan," http://ec.europa.eu/polska/news/documents/110207_strategia_pl.doc. Accessed: 15.03.2014. 
2. The use of the region's full potential in the field of research and innovation,

3. The implementation of the Charter for small enterprises: to promote entrepreneurship, strengthen SMEs and increase the efficient use of human resources,

4. Strengthening sustainable agriculture, forestry and fisheries. ${ }^{22}$ "

With reference to the conversion of the region in a place accessible and attractive the following items are listed:

1. "Improving access to energy markets, their performance and safety,

2. Improve internal and external transport links,

3. To maintain and enhance the attractiveness of the Baltic Sea region, in particular by education, youth, tourism, culture and health. ${ }^{23}$ "

As far as the conversion of RMB into a safe and protected area is concerned, the following tasks have been selected:

1. "Achievement of the leading position in the field of security and safety at sea By region,

2. Increase the capacity to respond to maritime accidents and protection against serious emergency situations,

3. Reducing the scale of cross-border crime and its effects. ${ }^{24}$ "

The Strategy is an internal document of the EU. However, its effectiveness and the effectiveness of the proposed solutions is higher in cooperation with nonEU countries for which the Baltic Sea is also an important resource. Among these countries are: Russia, Norway and Belarus. It is important to strengthen further cooperation with these countries, among others, through the northern dimension. In the Strategy there should be included frames for the further cooperation with non-EU countries, because only in this way the full cooperation in the region will allow the optimal socio-economic development and preservation of the environment. ${ }^{25}$

The geographical range of SUE RMB encompasses the macro-region around the Baltic Sea. Some issues apply to all countries in the region, and some (such as those relating to the quality of the water) apply only to the catchment. More specifically, SUE BSR covers the range of RMB 8 Member States belonging to

\footnotetext{
22 Ibidem.

23 Ibidem.

24 Ibidem.

25 Ibidem.
} 
the EU. However, in many aspects there is necessary cooperation with the other actors of the Baltic political scene. ${ }^{26}$

Cohesion policy is an important part of the Strategy. Owing to such a policy, over 50 billion Euros has been intended as the cost of the 2007-2013 investments in the region. The common fisheries policy is a tool that brings additional 1.25 billion Euros. However, it is necessary to adjust these measures to the Strategy. Part of the common agricultural policy is, in particular, the rural development, related to the environmental sustainability and prosperity in the region. The Seventh Framework Programme (FP7) and its financial tools can provide the scientific basis for the RMB sustainability. Other essential tools in the implementation of the Strategy are the trans-European transport and energy networks, European economic recovery plan, and the agreement on fishing between the EU and Russia. $^{27}$

In a press release, $\mathrm{RMB}$ was considered a good example of a macro-region. ${ }^{28}$ This strategy allows for drawing conclusions on the potential macro-region useful to other European macro-regions in the future. The Macro-regional approach was to ensure an EU new policy instrument demonstrating the joint efforts directed at the achievement of the EU objectives, effective territorial policy and sectoral policies on the basis of the common objectives of the governments. ${ }^{29}$

Yet another strategy is the EU Strategy for the Danube Region, a response to Commissioner Danuta Hübner's appeal dated for October 2008. She called for the creation of the EU policy directed at the Danube region as a whole involving both the impact on the economy and transport, and the EU environmental protection. The Member States representatives present at the open day in the Directorate-General began the discussion over the creation of the second EU Strategy. ${ }^{30}$

Formally, the process of creating the second macro-regional strategy was launched in February 2009. At that time, Austria and Romania requested the proposal for the development of such a strategy. ${ }^{31}$

26 Ibidem.

27 Ibidem.

28 The area consisting of separate administrative regions facing many common problems for which it is legitimate to adopt a common strategic approach.

29 Cf. "The Communication from the Commission to the European Parliament, the Council, the European Economic and Social Committee and the Committee of the Regions Concerning the European Union Strategy for the Baltic Sea Region."

30 www.osw.waw.pl/sites/default/files/PRACE_37.pdf. Accessed: 15.03.2014.

31 Ibidem. 
The theme of the strategy for the Danube region also appeared in June in the same year during the June meeting of the European Council. In the conclusions of the meeting, this Council asked the Commission of the EU to present the concept of a macro-regional strategy for the Danube area by the end of $2010 .{ }^{32}$

In the report presented by the Commission in 2010, there was a detailed elaboration of the opportunities and challenges facing the region and the Action Plan as part of a strategy designed to assist the integration and cooperation of the Danube region. As for the challenges, the Commission enumerated the following elements: mobility (as TEN-T corridor), energy (the development of renewable energy), environment (creation of a common policy on pollution), socio-economic items (in particular reducing disparities between the Member States), providing security and preventing organised crime, prevention of drought, floods and accidents of industrial pollution releasing. ${ }^{33}$

Owing to the social consultation a catalogue of chances has been developed including : the opening to the East (thanks to the Caucasus and Central Asia connections), solid education system, cultural, ethnic, and natural diversity (common tourist offer should be extended), and the possibility of the development of renewable energy sources. ${ }^{34}$

The Action Plan has been based on four assumptions:

- should give benefits,

- should foster development and involve a few countries or regions,

- initiatives should be consistent,

- project should be technically and financially feasible. ${ }^{35}$

The Action Plan has embraced the following areas of action:

- "A better combination of Danube region and the world,

- Improving mobility and multimodality,

- Inland navigation,

- Access by road, rail and air,

- Promotion of sustainable energy,

- The promotion of culture, tourism and social contacts,

- Environmental protection in the Danube region,

- Restore and maintain the high quality of the waters,

32 http://prasaeuropa.pl/press-releases/rada-europejska-w-brukseli-18-19-czerwca-2009-rkonkluzje-prezydencji. Accessed: 15.03.2014.

$33 \mathrm{http} / / /$ eurlex.europa.eu/Notice.do? mode=dbl\&lng1=pl,pl\&lang=\&lng2=bg,cs,da,de,el,e n,es,et,fi,fr,hu,it,lt,lv,mt,nl,pl,pt,ro,sk,sl,sv,\&val=551578:cs. Accessed: 15.03.2014.

34 Ibidem.

35 Ibidem. 
- Management of risks to the environment,

- Protection of biodiversity, landscapes and the quality of the air and soils,

- Building prosperity in the Danube region,

- The development of the knowledge for society through research, education and information technology,

- Promoting the competitiveness of enterprises, including the development of clusters,

- Investing in people and skills,

- Increasing the potential of the Danube region,

- Capacity of institutions and cooperation between them,

- Cooperation in order to improve safety and to combat organized and serious crime. ${ }^{36}$ ",

Observing the fate of regional cooperation from the Madrid Convention to the creation a macro-regional approach, the significant development of the concept of interregional relations can be observed. These relations have been evolving from promoting and supporting cross-border cooperation by the Member States to complete the EU macro-regional concept elaborated with the participation of the regions and organisations acting on their behalf. Within the next few years it will turn out whether the overall concepts fulfilled its function and enhanced internal cooperation in the EU.

\section{WORKS CITED}

“The Action Plan,” http://ec.europa.eu/polska/news/documents/110207_strategia_pl.doc Accessed: 15.03.2014.

Brodecki, Zdzisław (ed.). Regiony. Warszawa: Wydawnictwo Naukowe PWN 2005.

The BSSSC Resolution at the 16th Annual Conference of the Baltic Sea States Sub-Regional Cooperation (BSSSC) in Kaunas, Lithuania, 17-19 September 2008. The Archives of the Department of International Cooperation of the West Pomeranian Region.

"The Communication from the Commission to the European Parliament, the Council, the European Economic and Social Committee and the Committee of the Regions Concerning the European Union Strategy for the Baltic Sea Region," http://ec.europa. eu/regional_policy/sources/docoffic/official/communic/baltic/com_baltic_pl.pdf. Accessed: 15.03.2014.

36 Ibidem. 
Cross-border cooperation. Vol. VI: "The Perspective of Cross-Border Cooperation in the Baltic Sea after the Enlargement of the European Union to the East." Schwerin: The Archives of the Department of International Cooperation of the West Pomeranian Region 2004.

http://eurlex.europa.eu/Notice.do?mode=dbl\&lng1=pl,pl\&lang=\&lng2=bg,cs,da,de,el,en, es,et,fi,fr,hu,it,lt,lv,mt,nl,pl,pt,ro,sk,sl,sv,\&val=551578:cs. Accessed: 15.03.2014.

http://prasaeuropa.pl/press-releases/rada-europejska-w-brukseli-18-19-czerwca-2009-rkonkluzje-prezydencji . Accessed: 15.03.2014.

Jaskiernia, Jerzy. „Regionalizm jako wartość w systemach aksjologicznych Rady Europy i Unii Europejskiej.” Regiony Europy. Ed. A. Stępień-Kuczyńska, K. Dośpiał-Borysiak, R. Łoś. Toruń: Wydawnictwo Adam Marszałek 2009.

Kokocińska, Katarzyna. Regional Policy in Poland and in the European Union. Poznań: Wydawnictwo Naukowe Uniwersytetu im. Adama Mickiewicza 2009.

Latoszek, Ewa, Magdalena Proczak. International Organizations in Today's World. Warszawa: Wydawnictwo Naukowe Wydziału Zarządzania Uniwersytetu Warszawskiego 2006.

Tomaszewski, Krzysztof. Regiony w procesie integracji europejskiej. Kraków: Wolters Kluwer 2007.

www.osw.waw.pl/sites/default/files/PRACE_37.pdf. Accessed: 15.03.2014.

\section{Summary}

The cooperation of regional authorities in Europe is made possible via the existing international conventions and internal documents of the European Union. Studying the vicissitudes of the European regional cooperation from the Madrid Convention to the creation of a macro-regional approach, one cannot but notice the significant development of the concept of interregional relations. These relations have been evolving from the promotion and support cross-border cooperation by the Member States to its completion as the EU macro-regional concept elaborated with the participation of the regions and organisations acting on their behalf. Within the next few years it will turn out whether these concepts have in their entirety fulfilled their function and enhanced the internal EU cooperation.

Keywords: Baltic Sea Region, European Union 


\title{
WSPÓŁPRACA REGIONALNA W EUROPIE. OD KONWENCJI MADRYCKIEJ DO PODEJŚCIA MAKROREGIONALNEGO
}

\begin{abstract}
Streszczenie
W Europie współpraca organów regionalnych jest możliwa w oparciu o Konwencje międzynarodowe oraz dokumenty wewnętrzne Unii Europejskiej. Obserwując losy współpracy regionalnej od konwencji madryckiej do stworzenia podejścia makroregionalnego, można zaobserwować znaczny rozwój koncepcji stosunków międzyregionalnych. Stosunki te ewoluowały od popierania i wspierania współpracy transgranicznej przez Państwa do całościowych koncepcji makroregionalnych UE opracowanych z udziałem regionów i organizacji na ich rzecz działających. W ciągu najbliższych lat okaże się, czy całościowe koncepcje spełniły swoją funkcję i usprawniły współpracę wewnętrzną UE.
\end{abstract}

Słowa kluczowe: Region Morza Bałtyckiego, Unia Europejska 
